Удк: 005.2: [631.1: 001. 891]

DOI https://doi.org/10.32851/2708-0366/2021.7.10

Мухіна I.A.
кандидат економічних наук, доцент,
Херсонський державний аграрно-економічний університет
ORCID: https://orcid.org/0000-0002-9540-1899

Хорунжий I.B.

кандидат сільськогосподарських наук, доцент,

Херсонський державний аграрно-економічний університет

Muhina Irina, Horundjy Igor

Kherson State Agrarian and Economic University

\title{
ОБґРУНТУВАННЯ ВИБОРУ МІСІЇ НАУКОВО-ДОСЛІДНОГО ГОСПОДАРСТВА
}

\section{JUSTIFICATION OF THE CHOICE OF THE MISSION OF THE RESEARCH ENTERPRISE}

Конкурентне середовище ринку передбачає взаємодію в одному просторі економічних суб'єктів, інтереси яких часто є протилежними за змістом: підприємців, споживачів товарів та послуг, найманих працівників, постачальників сировини та матеріалів, партнерів, соціальних і політичних інституцій та ін. Серед інструментів стратегічного управління, що сприяє оптимальному поєднанню інтересів суб'єктів ринку, - місія підприємства. Вона створює соиіально-психологічні умови для гуманізації бізнесу та соиіалізації економіки у иілому. У дослідженні розглянуто питання теоретичних засад та практичних особливостей формування місії науково-дослідного господарства. $У$ ходi роботи над темою отримано результати, які мають самостійне наукове та практичне значення: запропоновано використовувати метод субоптимізачії для обгрунтування місї; визначено відмінності субоптимізації від оптимізації; рекомендовано визначати стратегічні иілі підприємства з урахуванням аналізу вимог учасників мікросередовищиа.

Ключові слова: місія підприємства, стратегічні иілі підприємства, елементи формування місії, субоптимізація, інтереси суб 'єктів ринку, учасники мікросередовища підприемства.

Конкурентная рыночная среда предполагает, что в одном пространстве могут взаимодействовать экономические субъекты, чьи интересы противоположны по смыслу: предприниматели, потребители товаров и услуг, наемные работники, поставщики сырья и материалов, партнеры, сочиальные и политические институты и прочие. Среди инструментов стратегического управления, которые способствуют оптимальному сочетанию интересов субъектов рынка, - миссия предприятия. Она создает социально-психологические условия для гуманизаџии бизнеса и социализации экономики в целом. В исследовании рассмотрены теоретические основы и практические особенности формирования миссии научно-исследовательского хозяйства. В ходе работы над темой получены результаты, имеюшие самостоятельное научное и практическое значение: предложено использовать метод субоптимизации для обоснования миссии; определень отличия субоптимизации от оптимизации; рекомендовано определять стратегические цели предприятия с учетом анализа требований участников микросреды.

Ключевые слова: миссия предприятия, стратегические цุели предприятия, элементы формирования миссии, субоптимизация, интересы субъектов рынка, участники микросреды предприятия.

The competitive environment of the market involves interaction in the same space of economic entities, whose interests are often opposite in meaning - entrepreneurs, consumers of goods and services, employees, suppliers of raw materials, partners, social and political institutions, and others. Therefore, answering the question: "How are we going to achieve an increase in the income of our enterprise?", the manager has to take into account both internal 
and external features of the environment, which are constantly changing over time, because the long-term functioning of the business is impossible in conflict conditions. Among the strategic management tools that contribute to the optimal combination of interests of market entities is the mission of the enterprise. It creates socio-psychological conditions for the humanization of business and the socialization of the economy as a whole. The study examines the theoretical foundations and practical features of the formation of the mission of a research economy on the example of the "Experimental farm "Kopany" of "the Institute of Irrigated Agriculture of the National Academy of Agrarian Sciences of Ukraine" of the Belozersky district of the Kherson region. The task is to improve the strategic management toolkit for a reasonable choice of the enterprise's mission. The study set the following tasks: determine the essence of the concept of the mission of the enterprise and its elements, to summarize the features of the functioning of research farms in the agricultural sector of Ukraine in comparison with other enterprises, substantiate the choice of the mission of the research farms based on the analysis of the economic and organizational indicators of the enterprise's activity related to the mission. In the course of work on the topic, results were obtained that have independent scientific and practical significance: it was proposed to use the suboptimization method to justify the mission; certain differences between suboptimization and optimization; it is recommended to determine the strategic goals of the enterprise taking into account the analysis of the requirements of the participants in the microenvironment.

Key words: mission of the enterprise, strategic goals of the enterprise, elements of the formation of the mission, suboptimization, interests of market participants, the participants of the microenvironment of the enterprise.

Постановка проблеми. Через складні економічні та політичні умови в Україні так і не була досягнута мета Державної цільової програми розвитку аграрного сектору економіки на період до 2020 р. - «створення організаційно-економічних умов для ефективного соціально спрямованого розвитку аграрного сектору» [1]. Отже, розв’язання цієї проблеми є актуальним і сьогодні.

Запорукою досягнення мети слугує розроблення такого важливого інструменту стратегічного управління, як місія підприємства, тому що його використання створює соціально-психологічні умови для оптимального поєднання протилежних за змістом інтересів суб'єктів внутрішнього і зовнішнього середовища підприємства й через це сприяє соціалізації економіки. Між тим практичним особливостям обгрунтування місії приділяють мало уваги, і майже відсутні дослідження щодо місії сільськогосподарського та наукового підприємства чи їх поєднання.

Аналіз останніх досліджень і публікацій. Свого часу інструментарієм стратегічного менеджменту глибоко займався американський учений російського походження I. Ансофф; значний внесок у розроблення поняття місії зробили М. Портер, А. Чандлер, П. Друкер, П. Кругман, О. Віханський, І. Гурков, Г. Гольдштейн.

Українські вчені також працюють у цьому напрямі, серед них: Є. Кайлюк, Г. Кіндрацька, Д. Горєлов, С. Большенко, В. Андрєєва, В. Гриненко, Г. Осовська, П. Сладкевич, 3. Шершньова та ін.

Формулювання цілей статті. Мета статті - розглянути теоретичні засади та практичні особливості застосування місії у системі стратегічного управління, визначити напрями вдосконалення інструментарію для обгрунтованого вибору місії підприємства.

Завдання:

1) визначити сутність поняття місії підприємства та їі елементів;

2) узагальнити особливості функціонування науково-дослідних господарств аграрного сектору України порівняно з іншими підприємствами;

3) обгрунтувати вибір місії науково-дослідного господарства на основі аналізу пов'язаних із місією економічних та організаційних показників діяльності підприємства.

Об’єктом дослідження було дослідне господарство «Копані» Інституту зрошуваного землеробства Національної академії аграрних наук України (скорочено ДП «ДГ «Копані» НААНУ») Білозерського району Херсонської області. 
Серед методів дослідження: спостереження, порівняння, групування, аналіз і синтез, табличний, графічний; статистичний; порівняння, а також субоптимізація для формування місії підприємства.

Інформативною базою слугували дані статистичної звітності, законодавчі акти, періодичні видання, показники економічної та організаційної діяльності ДП «ДГ «Копані» НААНУ», Інтернет-джерела та особисті спостереження.

Виклад основного матеріалу. Доходність підприємства є ключовою метою для його власників. Проте ринок надає можливість збільшення доходів тільки через задоволення споживчого попиту, i, з його боку, доходність - лише внутрішня проблема підприємства. Отже, і місію (призначення) підприємства потрібно шукати поза його межами, а саме серед користувачів товарів та послуг підприємства.

Формуючи у клієнтів уявлення про себе, підприємству слід позиціонуватися як засіб задоволення певних потреб клієнтів, а не тільки як виробник товарів чи послуг, тому що «товари та технології старіють, а основні потреби залишаються» [2].

Водночас реалізація економічних цілей здійснюється не лише за допомогою капіталу власників, а й праці співробітників підприємства, які мають відмінні від власників особисті інтереси, тим не менше вони є частиною загального процесу виробництва і реалізації продукції.

Поєднання цілей важливе для розуміння працівниками своїх завдань. Через це місія функціонує у двох формах:

a) для зовнішніх учасників ринку - лаконічний і змістовно насичений слоган (кредо) та чітко сприйнятий покупцем образ підприємства (імідж);

б) для співробітників - більш детальна й осмислена мета функціонування підприємства, яка окреслює сферу його діяльності, способи досягнення економічних цілей, способи взаємодії із суспільним середовищем та ін.

Між тим головним завданням місії є поєднання протилежних за змістом інтересів ключових учасників ринкового середовища: власників, споживачів та працівників. Власники найчастіше прагнуть отримати якомога більший прибуток від своєї діяльності, покупці - якісний продукт за нижчу ціну, а наймані працівники - максимально можливу заробітну плату (рис. 1).

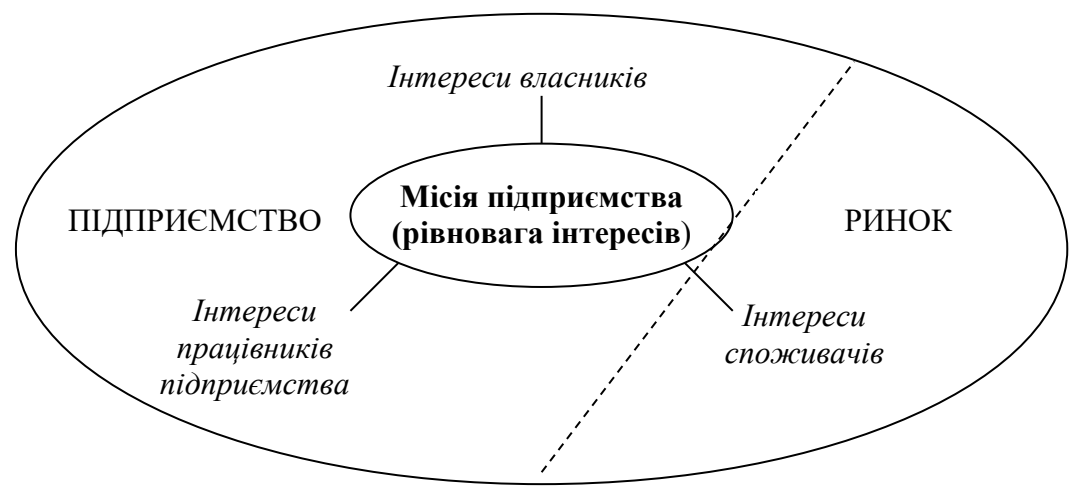

Рис. 1. Відносини ключових учасників ринкового середовища через місію підприємства

Джерело: побудовано на основі [2-4]

Місія рідко змінюється і мало залежить від поточного стану справ, а переглядається лише через зміну потреб або появу нових можливостей. Завдяки цьому цілі під- 
приємства стають внутрішньо узгодженими, що важливо для забезпечення довготривалих зовнішніх конкурентних позицій.

Оскільки завдання місії - поєднати протилежні за економічною метою інтереси суб'єктів мікросередовища, то і вирішення потребує відмінних від традиційних підходів до визначення ролі підприємства та його завдань.

Таким методом була вибрана субоптимізація замість оптимізації. Розглянемо особливості цих методів у табл. 1 .

Таблиця 1

Зміна парадигм щодо функціонування підприсмства

\begin{tabular}{|c|c|c|}
\hline \multirow{2}{*}{ Уявлення } & \multicolumn{2}{|c|}{ Парадигма } \\
\hline & Оптимізація & Субоптимізація \\
\hline Підприємство & $\begin{array}{l}\text { Засіб досягнення економічної } \\
\text { (або іншої) мети власників }\end{array}$ & $\begin{array}{l}\text { Підсистема в складній системі } \\
\text { зовнішніх відносин }\end{array}$ \\
\hline $\begin{array}{l}\text { Мета } \\
\text { функціонування }\end{array}$ & $\begin{array}{l}\text { Задовольняти інтереси } \\
\text { власників }\end{array}$ & $\begin{array}{l}\text { Задовольняти потреби більшості } \\
\text { учасників цілісного середовища }\end{array}$ \\
\hline Діяльність & $\begin{array}{l}\text { Можна описати за допомогою } \\
\text { критерію оптимальності }\end{array}$ & $\begin{array}{l}\text { Не можна описати та визначити одним } \\
\text { показником }\end{array}$ \\
\hline Цілеспрямування & $\begin{array}{l}\text { В організації повинна бути } \\
\text { єдина ціль }\end{array}$ & $\begin{array}{l}\text { Множинність цілей потрібна для } \\
\text { відображення різноманіття зв’язків } \\
\text { організації зі складним, поділеним на } \\
\text { сегменти та елементи середовищем }\end{array}$ \\
\hline Працівники & $\begin{array}{l}\text { Усі учасники підприємства } \\
\text { працюють над досягненням } \\
\text { єдиної економічної мети }\end{array}$ & $\begin{array}{l}\text { Сдність цілей усередині організації } \\
\text { уявна: кожна група та індивід } \\
\text { користуються власними інтересами, що } \\
\text { містить ознаки потенційного конфлікту }\end{array}$ \\
\hline Реалізація мети & $\begin{array}{l}\text { Довгострокові цілі } \\
\text { розбиваються на підцілі та } \\
\text { етапи їх досягнення }\end{array}$ & $\begin{array}{l}\text { Довго- й короткострокові цілі } \\
\text { підприємства не збігаються через зміну } \\
\text { як потреб підприємства, так і змісту } \\
\text { управлінських рішень із плином часу }\end{array}$ \\
\hline $\begin{array}{l}\text { Прийняття } \\
\text { управлінських } \\
\text { рішень }\end{array}$ & $\begin{array}{l}\text { Керівники приймають } \\
\text { обгрунтоване рішення на } \\
\text { основі аналізу достатньої } \\
\text { кількості інформації }\end{array}$ & $\begin{array}{l}\text { Керівники приймають рішення в умовах } \\
\text { хронічної нестачі необхідної інформації, } \\
\text { тому фактичне досягнення критерію } \\
\text { оптимальності неможливе }\end{array}$ \\
\hline
\end{tabular}

Джерело: узагальнено на основі [3; 4]

На відміну від оптимізації субоптимізація ставить метою й умовою функціонування підприємства задоволення потреб якомога більшого числа учасників мікросередовища, в якому підприємство розглядається як одна з підсистем у цілісній системі зовнішніх відносин.

Для обгрунтованого вибору місії науково-дослідного господарства потрібно визначити особливості функціонування цих підприємств порівняно $з$ традиційними аграрними. Це допоможе скористатися сприятливими чинниками та зменшити тиск несприятливих.

Відзначимо, що за останні два десятиріччя на відміну від галузей промисловості аграрна сфера України активно нарощує свій потенціал. Підтвердженням цього слугує інтенсифікація виробництва: підвищення більше як на третину обсягу виробництва рослинницької продукції без збільшення розміру посівних площ, переорієнтація на прибуткові види продукції, завоювання позицій на експортних ринках, розвиток агрохолдингів, залучення інвестицій на міжнародних фондових ринках. Отже, сільське господарство перетворюється на агробізнес і стає привабливою галуззю економіки. 
У зв’язку із цим зростає значення аграрної науки як для забезпечення продовольчої безпеки країни, так і експорту продуктів харчування. Завдання науки - пропонувати аграрному бізнесу інноваційні розробки, які підвищують доходність підприємства [5]. Продуцентами інновацій виступають науково-дослідні господарства, які поєднують сільськогосподарську діяльність із науковою.

Особливістю функціонування цих підприємств $є$ те, що у своїй переважній більшості вони є державними і підпорядковуються Міністерству освіти та науки (MOH) України [6].

Науково-дослідним підприємствам, які включаються до Реєстру наукових установ, наказом МОН надається підтримка держави, тому більша частина цих підприємств залежна від бюджетного фінансування. Відповідно до Положення, ці підприємства мають такі особливості:

- користуються податковими пільгами відповідно до законодавства;

- не можуть змінювати вид наукової і науково-технічної діяльності;

- зобов'язані не менш як 50\% доходу від своєї основної діяльності спрямовувати на проведення ініціативних науково-дослідних робіт та розвиток дослідницької матеріально-технічної бази;

- забезпечують не менш як 70\% основної наукової або науково-технічної діяльності у загальному річному обсязі виконаних робіт [7].

Велике значення розвиток агарної науки має для економіки Херсонської області. Так, в області функціонує 17 науково-дослідних організацій та три навчальні заклади, які здійснюють підготовку фахівців аграрного спрямування.

Найзначніші 3 науково-дослідних організацій - біосферний заповідник «Асканія-Нова», Інститут землеробства Південного регіону, Інститут рису, дослідне господарство південного овочівництва і баштанництва, Інститут тваринництва степових районів імені М.Ф. Іванова «Асканія-Нова», Національний науковий селекційно-генетичний центр вівчарства.

Усі організації мають розгалужену мережу своїх дослідницьких господарств, які не лише впроваджують у виробництво наукові розробки своїх центрів, а й проводять власні дослідження щодо рослинницьких культур та сільськогосподарських тварин.

Тобто серед чинників, які суттєво впливають на формування місії науково-дослідного господарства, можна виділити:

1) залежність від обсягу державного фінансування;

2) попит суспільства на наукові розробки в аграрному секторі;

3) напрями поліпшення здобутків підприємства за допомогою науки.

Досліджуване господарство - ДП «ДГ «Копані» НААНУ» розташоване в Білозерському районі Херсонської області. Воно входить у систему Української академії аграрних наук і безпосередньо підпорядковується Інституту землеробства Південного регіону. Це одне $з$ найстаріших дослідних господарств Херсонщини, яке успішно функціонує понад 65 років [8].

ДП «ДГ «Копані» НААНУ» $є$ державним сільськогосподарським статутним суб'єктом підприємницької діяльності, що здійснює дослідну, господарську і комерційну діяльність із метою досягнення позитивних економічних результатів та одержання прибутку.

Мета діяльності господарства - забезпечення науковців умовами для проведення досліджень, випробувань, апробації й упровадження наукових розробок у виробництво, а також вирощування і збут продукції рослинництва належної якості за доступну ціну. Підприємство займається виробництвом оригінального, елітного та репродукційного насіння сільськогосподарських культур та саджанців.

Основними напрямами діяльності ДП «ДГ «Копані» НААНУ» $:$

- активне сприяння науковій установі, якій воно підпорядковане, а також іншим 
науковим установам у роботі з проведення наукових дослідів, виробничої перевірки і впровадження науково-технічних розробок;

- сприяння на взаємовигідній основі науковим установам в їхній діяльності 3 поширенню серед державних підприємств, організацій та інших господарюючих суб'єктів досягнень науки, техніки і передового досвіду у виробництво;

- виробництво оригінального, елітного та репродукційного насіння сільськогосподарських культур та саджанців [8; 9].

Економічна діяльність підприємства включає заняття сільським господарством (рослинництвом), мисливством та лісовим господарством. Перший вид діяльності $є$ головним.

Склад і структура земельних угідь підприємства залишаються незмінними протягом останніх 15 років. Площа під дослідними полями становить понад $60 \%$ від загальної, що свідчить про високий рівень наукових досліджень на підприємстві.

У цілому функціонування ДП «ДГ «Копані» НААНУ» є стабільним і прибутковим, тому на найближчі 10-15 років зміни напряму діяльності не заплановано. Те саме стосується форми власності.

Особливістю сучасного етапу сільськогосподарського виробництва в Україні $\epsilon$ відсутність конкурентної боротьби серед товаровиробників. Це пов'язано зі зростанням попиту на продукцію, яка не лише споживається в країні, а й у знач-ній кількості експортується за її межі. Тому чисельність клієнтів ДП «ДГ «Копані» НААНУ» постійно зростає.

У переважній більшості клієнтами підприємства виступають сільськогосподарські та переробні підприємства, фермерські господарства, особисті господарства громадян, населення Херсонської та Миколаївської областей. Характеристику відносин підприємства у мікросередовищі представлено в табл. 2.

Таблиця 2

Характеристика суб’сктів мікросередовища ДП «ДГ «Копані» НААНУ»

\begin{tabular}{|c|c|c|}
\hline $\begin{array}{c}\text { Суб'скти } \\
\text { мікросередовища }\end{array}$ & $\begin{array}{c}\text { Хто вони, } \\
\text { де розташовані? }\end{array}$ & Форма відносин із підприсмством \\
\hline 1 & 2 & 3 \\
\hline Клієнти & $\begin{array}{l}\text { сільськогосподарські та } \\
\text { переробні підприємства, } \\
\text { фермерські господарства, } \\
\text { оптово-посередницькі фірми, } \\
\text { особисті господарства } \\
\text { громадян, населення } \\
\text { Херсонської та Миколаївської } \\
\text { областей }\end{array}$ & $\begin{array}{l}\text { - купують продукцію рослинництва та } \\
\text { насіннєвий матеріал для виробництва } \\
\text { с.-г. продукції, переробки, перепродажу } \\
\text { та особистого споживання; } \\
\text { - отримують консультації щодо } \\
\text { виробництва продукції з купленого } \\
\text { насіння сортів та гібридів }\end{array}$ \\
\hline Партнери & $\begin{array}{l}\text { провідна установа - Інститут } \\
\text { зрошуваного землеробства } \\
\text { НААНУ, інші наукові } \\
\text { господарства та установи, } \\
\text { с-г. підприємства усіх } \\
\text { форм власності, переважно } \\
\text { Херсонської області }\end{array}$ & $\begin{array}{l}\text { - сприяння провідній та іншим } \\
\text { науковим установам роботі з } \\
\text { проведення дослідів, виробничої } \\
\text { перевірки і впровадження науково- } \\
\text { технічних розробок; } \\
\text { - поширення серед господарюючих } \\
\text { суб'єктів досягнень науки, техніки і } \\
\text { передового досвіду у виробництво; } \\
\text { - сумісне виробництво оригінального, } \\
\text { елітного та репродукційного насіння, } \\
\text { сільськогосподарських культур та } \\
\text { саджанців }\end{array}$ \\
\hline
\end{tabular}


Продовження Таблиці 2

\begin{tabular}{|c|c|c|}
\hline 1 & 2 & 3 \\
\hline Постачальники & $\begin{array}{l}\text { оптово-посередницькі фірми, } \\
\text { постачальники сировини, } \\
\text { виробники хімічних та } \\
\text { біологічних препаратів, } \\
\text { мінеральних та органічних } \\
\text { добрив, засобів захисту } \\
\text { рослин Херсонської області та } \\
\text { України }\end{array}$ & $\begin{array}{l}\text { - реалізують підприємству продукцію, } \\
\text { необхідну для забезпечення } \\
\text { виробництва товарної продукції та } \\
\text { насіння високих репродукцій }\end{array}$ \\
\hline
\end{tabular}

Як показує аналіз наведеної інформації, наукова діяльність є домінуючою на підприємстві. Їй підпорядковуються всі інші види діяльності та відносини із зовнішніми суб'єктами.

Проведений аналіз дав змогу визначити, які саме потреби мають учасники зовнішнього середовища до ДП ДГ «Копані» НААНУ». Схему цих потреб представлено на рис. 2.

\section{М І К Р О С Е Р Е Д О В ИЩЕ П І Д Р И С М Т В А}

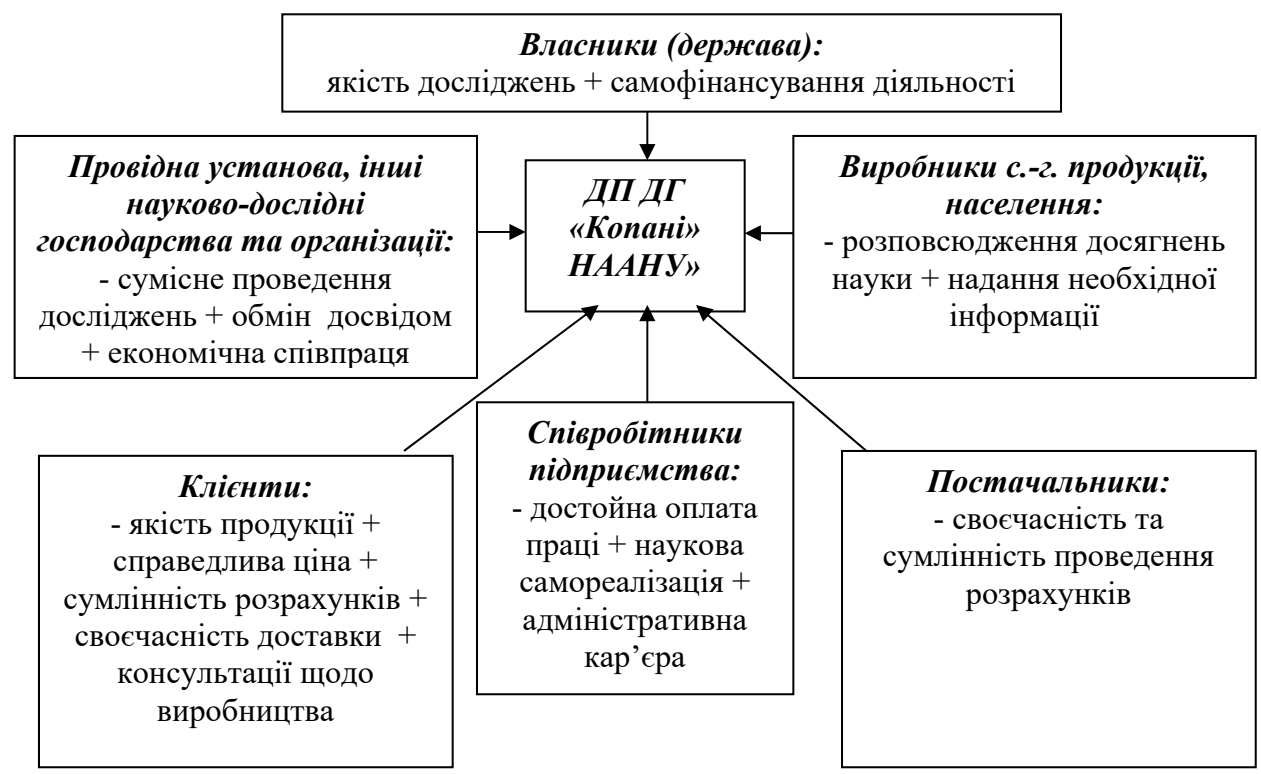

Рис. 2. Схема потреб суб'єктів мікросередовища по відношенню до ДП ДГ «Копані» НААНУ»

Джерело: розроблено на основі [8-10]

Для того щоб визначитися з пріоритетним напрямом місії, потрібно розібратися, який із видів діяльності підприємства є найбільш значущим для зовнішніх суб'єктів мікросередовища. Для цього ми згрупували вимоги основних і другорядних учасників за видами діяльності: економічна, наукова, дорадча та адміністративна і порахували їх кількість (табл. 3).

Аналіз вимог показав, що для основних учасників економічна діяльність підприємства є найбільш значущою, наукова займає другу позицію, а дорадча - третю. Від- 
значимо, що для більшості другорядних учасників наукова діяльність виступає пріоритетною.

Таблиця 3

Групування вимог суб'єктів мікросередовища ДП ДГ «Копані» НААНУ» за видами економічної діяльності

\begin{tabular}{|c|c|c|c|c|c|}
\hline & \multicolumn{4}{|c|}{ Види діяльності } \\
\hline & & Економічна & Наукова & Дорадча & Адміністративна \\
\hline \multirow{9}{*}{ 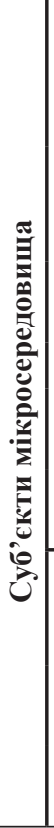 } & \multirow{6}{*}{ 章 } & 1. Якість продукції & $\begin{array}{l}\text { 1. Якість } \\
\text { досліджень }\end{array}$ & $\begin{array}{l}\text { 1. Консультації } \\
\text { щодо } \\
\text { виробництва } \\
\text { продукції }\end{array}$ & $\begin{array}{l}\text { 1. Адміністра- } \\
\text { тивна кар'єра }\end{array}$ \\
\hline & & $\begin{array}{l}\text { 2. Сумлінність } \\
\text { розрахунків }\end{array}$ & $\begin{array}{l}\text { 2. Наукова } \\
\text { самореалізація } \\
\text { співробітників }\end{array}$ & - & - \\
\hline & & $\begin{array}{l}\text { 3. Справедлива ціна } \\
\text { продукції }\end{array}$ & - & - & - \\
\hline & & 4. Своєчасна доставка & - & - & - \\
\hline & & $\begin{array}{c}\text { 5. Самофінансування } \\
\text { діяльності }\end{array}$ & - & - & - \\
\hline & & $\begin{array}{l}\text { 6. Достойна оплата } \\
\text { праці } \\
\end{array}$ & - & - & - \\
\hline & \multirow{3}{*}{ 言 } & $\begin{array}{l}\text { 7. Своєчасність } \\
\text { та сумлінність } \\
\text { розрахунків }\end{array}$ & $\begin{array}{l}\text { 3. Сумісне } \\
\text { проведення } \\
\text { досліджень }\end{array}$ & $\begin{array}{l}\text { 2. Надання } \\
\text { необхідної } \\
\text { інформації }\end{array}$ & - \\
\hline & & $\begin{array}{c}\text { 8. Сумісна економічна } \\
\text { діяльність }\end{array}$ & 4. Обмін досвідом & - & - \\
\hline & & - & $\begin{array}{l}\text { 5. Поширення } \\
\text { досягнень науки }\end{array}$ & - & - \\
\hline
\end{tabular}

Джерело: розроблено на основі [2; 3; 8-10]

Оскільки головною умовою отримання доходів ДП ДГ «Копані» НААНУ» є взаємодія $з$ клієнтами, то адресність місії повинна бути звернена саме до них. Разом із цим наукова діяльність служить вагомою конкурентною перевагою підприємства та його особливою функцією.

Зважаючи на стратегічні перспективи, підприємству слід розширювати свою дорадчу та інформаційну діяльність, підвищувати їі якість. Це дасть змогу не лише підтримувати зв'язки зі своїми діючими клієнтами та партнерами, а й залучати нових.

Отже, місію господарства можна окреслити за такими напрямами:

- сприяння економічному розвитку аграрної сфери через реалізацію якісної продукції рослинництва та насіння високих репродукцій, вироблених за новітніми технологіями;

- надання дорадчих послуг щодо технології виробництва продукції своїм клієнтам, партнерам із бізнесу та науки;

- співпраця з іншими науковими організаціями для розвитку науки та проведення наукових досліджень;

- розповсюдження досягнень науки, надання необхідної інформації клієнтам і населенню через засоби інформації, Інтернет-мережу, наукові та інші видання.

Дані позиції можуть слугувати розширеною формою місії для внутрішнього використання, але для того щоб вона ефективно діяла та запам'ятовувалася, краще 
виобрати лаконічну форму. Рекомендованою формою стратегічної місії може слугувати така:

«Ми забезпечимо нашим покупцям якісну продукцію, партнерам - співпрацю та допомогу, науці - нові досягнення, співробітникам - стале благополуччя!».

У ній на перший план виходить господарська діяльність як необхідна умова існування підприємства в конкурентному середовищі. Далі, в порядку значущості, - шляхи досягнення поставленої стратегічної мети: сприяння інноваційному розвитку аграрної сфери та створення умов для соціалізації внутрішнього середовища.

Висновки. Місія є ідейною серцевиною підприємства, яка поєднує різні за спрямованістю інтереси економічних суб'єктів ринку. Крізь іiї призму складаються довготермінові цілі. Вона будується на суспільній користі від економічної діяльності.

Проведений аналіз потреб зовнішніх учасників мікросередовища дав змогу встановити пріоритети серед видів діяльності підприємства та обгрунтувати вибір місії ДП ДГ «Копані» НААНУ».

\section{Список використаних джерел:}

1. Концепція Державної цільової програми розвитку аграрного сектору економіки на період до 2020 року. URL: http://minagro.gov.ua/apk?nid=16822 (дата звернення: 07.05.2021).

2. Кіндрацька Г.І. Стратегічний менеджмент ; 2-е вид., перероб і доп. Київ : Знання, 2010. $406 \mathrm{c}$.

3. Субоптимизация производства. URL: http://www.avtomatika-ufa.ru/sistema41.html (дата звернення: 03.05.2021).

4. Шершньова 3.С. Стратегічне управління : підручник ; 2-е вид., перероб. і доп. Київ : КНЕУ, 2004. 699 c.

5. Горєлов Д.О., Большенко С.Ф. Стратегія підприємства. Харків : ХНАДУ, 2010. 133 с.

6. Закон України «Про наукову і науково-технічну діяльність». URL: https://zakon.rada.gov.ua/ laws/show/848-19\#Tехt (дата звернення: 15.05.2021).

7. Положення про Державний реєстр наукових установ, яким надається підтримка держави : Постанова Кабінету Міністрів України від 23 квітня 2001 р. № 380. URL: https://zakon.rada.gov.ua/laws/show/380-2001-\%D0\%BF\#Text (дата звернення: 15.05.2021).

8. Державне підприємство «Дослідне господарство «Копані» I3 HAAHУ. URL: http://izpr.org.ua/merezha-institutu/dp-dg-kopani.html (дата звернення: 18.05/2021).

9. Економічні паспорти за 2000-2019рр. ДП «ДГ «Копані» ІЗ НААНУ».

10. Кайлюк Є.М., Андрєєва В.М., Гриненко В.В. Стратегічний менеджмент. Харків : ХНАМГ, 2010. 279 с.

\section{References:}

1. Koncepcija Derzhavnoji ciljovoji proghramy rozvytku aghrarnogho sektoru ekonomiky na period do 2020 roku [The concept of the State target program for the development of the agricultural sector of the economy until 2020]. Available at: http://minagro.gov.ua/apk?nid=16822 (accessed 07 May 2021).

2. Kindracjka Gh.I. (2010) Strateghichnyj menedzhment [Strategic management]. Kyiv: Znannya. (in Ukrainian)

3. Suboptimizatsiya proizvodstva [Suboptimization of production]. Available at: http://www.avtomatika-ufa.ru/sistema41.html (accessed 03 May 2021).

4. Shershnjova Z.Je. (2004) Strateghichne upravlinnja [Strategic management]. Kyiv: KNEU. (in Ukrainian)

5. Goryelov D.O., Bolshenko S.F. (2010) Strateghija pidpryjemstva [Enterprise strategy]. Kharkiv: KhNADU. (in Ukrainian)

6. Zakon Ukrayiny «Pro naukovu i naukovo-texnichnu diyalnist» [Law of Ukraine "On Scientific and Scientific-Technical Activity"]. Available at: https://zakon.rada.gov.ua/laws/show/848-19\#Text (accessed 15 May 2021).

7. Polozhennja pro Derzhavnyj rejestr naukovykh ustanov, jakym nadajetjsja pidtrymka derzhavy postanovoyu Kabinetu Ministriv Ukrayiny vid 23 kvitnya 2001 r. № 380 [Regulations on the State Register of Scientific Institutions Provided with State Support by the Resolution of the Cabi- 
net of Ministers of Ukraine of April 23, 2001 № 380]. Available at: https://zakon.rada.gov.ua/laws/ show/380-2001-\%D0\%BF\#Text (accessed (accessed 15 May 2021).

8. Derzhavne pidpryemstvo «Doslidne gospodarstvo «Kopani» IZ NAANU [State Enterprise "Experimental Farm" Kopani "of the Institute of Irrigated Agriculture of the National Academy of Agrarian Sciences of Ukraine]. Available at: http://izpr.org.ua/merezha-institutu/dp-dg-kopani.html (accessed 18 May 2021).

9. Ekonomichni pasporty za 2000-2019 rr. DP «DG «Kopani» IZ NAANU» [Economic passports for 2000-2019 of the Kopani Experimental Farm of the Institute of Irrigated Agriculture of the National Academy of Agrarian Sciences of Ukraine].

10. Kajlyuk Ye.M., Andryeyeva V.M., Grynenko V.V. (2010) Strateghichnyj menedzhment [Strategic management]. Kharkiv: KhNAMG. (in Ukrainian) 